\title{
VPS18 wt Allele
}

National Cancer Institute

\section{Source}

National Cancer Institute. VPS18 wt Allele. NCI Thesaurus. Code C105600.

Human VPS18 wild-type allele is located within 15q14-q15 and is approximately $10 \mathrm{~kb}$ in length. This allele, which encodes vacuolar protein sorting-associated protein 18 , plays a role in the segregation of intracellular molecules into distinct organelles. 